\title{
ORIGINAL PREFACE TO KATAKOMBY XX VEKA: VOSPOMINANIIA
}

\author{
ARCHPRIEST ALEKSANDR MEN
}

“The Catacomb Church" ... One often encounters mention of it in the pages devoted to the new history of Russian Orthodoxy. Most often, these citations do not exceed two-three words or conjectures. This is not surprising, since there does not exist a complete collection of documents and eyewitness accounts, even about those phenomena and events in the life of the Church during this period, which took place in plain view of everyone. It is even more difficult to collect information about that which, by its very name, tells the story about the existence of "the underground church."

Several accounts deny the reality of the "catacomb church," while others disseminate extremely inauthentic information about it. Did it exist in reality, and if so, what was it like? In order to answer these questions, it is necessary briefly to touch on the history of the church division, which emerged in the period between the two world wars.

Since the seventeenth century, the epoch of the Old Believers' schism, the Church in Russia hardly lived through such a stormy period, full of dramatic events, as it did in the first half of our century. The prerevolutionary years of the twentieth century were not peaceful, and attempts were made to free the Church from the guardianship of the government. Although a sizable part of the clergy and laypeople was accustomed to the existing (synodal) situation, more and more persistently voices were raised, calling for the renaissance and renovation of church life. Desperately waiting for change, many priests developed very radical views, and some came out almost as "leftists." 55

The appeal to the Orthodox Church of leading representatives of the intelligentsia (S. Bulgakov, N. Berdiaev, P. Florenskii, S. Frank, V. Ern, V. Sventsitskii, and many others) contributed to the enlivening of discussion about troubling questions, related, in part, to reexamining the relationship of the Church to the government and to social life.

Because of the government's opposition, an All-Russian Sobor that aspired to become the voice of the Church and define its future road could not meet before the revolution. ${ }^{56}$ Therefore, the Sobor could open only in 1917, after the collapse of the monarchy, when the country had already entered a period 
of war and revolution. The resolutions of the Sobor were not realized in practice. A new epoch of Russian history had begun.

The October events of 1917 immediately brought the Church into conflict with the new Bolshevik government. This happened for two reasons. On one hand, a significant part of the church leadership, still closely connected with the former governing structure, was not prepared for such a transformation. On the other hand, the government openly proclaimed its goal to eradicate completely "religious prejudices." In the very first year of the revolution, the Bolsheviks created a plan to close all churches and forbid the sacrament of the Eucharist. Although the government did not carry out this plan in full, the onslaught rained down on the Church and exceeded in its power everything that history had known from the time of the Roman emperors and the French Revolution. Elected by the Sobor, Patriarch Tikhon, who courageously defended the Church, was arrested in 1922, and shortly thereafter the so-called Renovationist Schism took place. ${ }^{57}$ Its initiators, promising believers to introduce long-awaited church reforms, had as its main objective to place the church in the same relationship to the government that had existed before the revolution. ${ }^{58}$

The Renovationist movement's "sobor" passed a series of fairly unsuccessful and inopportune innovations, but its main goal entailed the proclamation of its political platform. Among other things, the documents of the "sobor" declared capitalism a mortal sin but revolution — an accomplishment of evangelical desires. ${ }^{59}$

Having the support and assistance of the government organs, the unauthorized Higher Ecclesiastical Administration (VTsU) seized the majority of churches, both in large cities and in the provinces. Nevertheless, public recognition of the so-called Living Church was not achieved. After Patriarch Tikhon was released from prison-which came about through the pressure of world public opinion - those church leaders who remained loyal to the patriarch rallied once again. This created confusion in the ranks of the Renovationists. Furthermore, a struggle between different factions began to tear their movement apart. Each day, the relationship of many believers to "the Red Church" (the Renovationists) became all the more suspicious and hostile.

After his release from prison, Patriarch Tikhon tried to make peace with the government but without making any compromises that might undermine church life. His death in 1925, however, awakened in the governing authorities hope that a compromise with the Church finally could be reached. But the church leaders appointed by the patriarch resolutely continued his line. As a result, the office of patriarch remained vacant for a long time. ${ }^{60}$ 
In the West, at the end of the 1920s, a broad campaign developed for the defense of Christianity in Russia, which was given the name of "spiritual crusade" (dukhovnyi krestovyi pokhod). The campaign offered a response to mass repressions, which a majority of our bishops and a large number of priests and active laypeople who had remained loyal to Patriarch Tikhon had suffered. Churches and monasteries were being closed; even, earlier, religious schools were shut down; many thousands of religious believers - priests, monks, laypeople, both men and women - filled prisons, labor camps, and distant places of exile. The persecutions were officially masked (truthfully, not especially carefully) under the slogan "the struggle with counterrevolution."

During this time, Metropolitan Sergii (Stragorodskii), fulfilling his responsibilities as keeper of the patriarchal seat (mestobliustitel', patriarchal locum tenens, interim patriarch) spoke out, both in a declaration and interview, in which, for tactical reasons, he denied the existence of religious oppression in Russia. ${ }^{61}$

Wanting to secure the "legalization" of the Church within the framework of the Soviet order, he made a series of concessions, making possible control over the life of the Church. ${ }^{62}$ These concessions met with a negative response from many of his colleagues and laypeople. Soviet historians acknowledge that Metropolitan Sergii attempted to "gain the initiative" from the Renovationists, having made the patriarchal Church completely loyal [to the Soviet government]. ${ }^{63}$

Opponents of the metropolitan's course of action maintained that his action did not help the Church, because the governing power did not change its principal relationship to the Orthodox faith, and by no means did the government intend to become reconciled with the existence of the Church. At most, what the government (temporarily) could agree upon was the creation of an obedient marionette hierarchy, which would lead believers until the government could completely eradicate the influence of religion in the country. Supporters of the "Sergievskaia line" in the Church argued that, in the present complex situation, the path of compromise was the only possibility. Leaders of the Moscow patriarchate have maintained this point of view to the present. ${ }^{64}$

Not enough time has passed yet for an objective historical evaluation of the affair of Metropolitan Sergii, who became patriarch in $1943 .{ }^{65}$ It should be recognized, however, that he and his successors managed to ascend above the Renovationists and achieve an elementary stabilization in the Church's situation in the country.

The Second World War played an enormous role in the transformation of the Church's status, during which the patriarchate (as did also the 
Renovationists) took a patriotic position. Stalin valued the role of the Church as a means of strengthening the people's spirit, and he showed sympathy for it. Between the two courses, he preferred the Sergievskaia line as more traditional, corresponding more than the other one to the perspectives of believers and corresponding more also to his own great power tastes. ${ }^{66}$ He liquidated the Renovationists and, in 1945, decided to summon the Church Sobor to elect a patriarch. With his agreement, thousands of churches were opened, and religious schools were revived. In many believers, hopes were then awakened that the time of oppression had passed. Further events, however, revealed that small concessions coming from the government were followed with large concessions required from the church hierarchy; sometimes concessions made to the Church bore no results. This became especially clear during the Khrushchev period, when, in spite of the well-known loosening of social life, the government subjected the Church to new pressures (the mass closing of churches and religious schools and the strengthening of antireligious propaganda began again) ${ }^{67}$

But let us return to the 1920s. A series of representatives of the bishops and clergy, disagreeing with the policy of Metropolitan Sergii, did not follow him. Referring to the permission granted them by Patriarch Tikhon, in time of need, to form temporary independent associations (avtokefalii) of bishops ${ }^{68}$ many of them formed independent groups (mainly in Moscow and Leningrad). From the point of view of the government, these independent groups represented a dangerous church opposition. The majority of unruly hierarchs were arrested, but from exile and from the camps, they continued to lead their priests and "flock." Those who remained in freedom went into an illegal status and secretly celebrated the liturgy in private homes. Thus emerged the phenomenon subsequently given the name "Catacomb Church." ${ }^{69}$

In the Moscow region (oblast'), to the Catacomb Church belonged Archimandrite Serafim (Batiukov); Fr. Pyotr Shipkov, ${ }^{70}$ who in the past had served as secretary to Patriarch Tikhon; Ieromonakh Ieraks (Bocharev) $;^{71}$ the priests Vladimir Bogdanov, Vladimir Krivolutskii, ${ }^{72}$ Konstantin Vsekhsviatskii, Aleksei Gabriianik, ${ }^{73}$ and Dmitrii Kriuchkov, ${ }^{74}$ and others. The majority of them considered Bishop Afanasii (Sakharov) as their bishop. ${ }^{75}$ In 1945, the Catacomb Church de facto ceased its existence. On one hand, the government hunted down and arrested almost all members of the priesthood; on the other hand, after the Sobor in 1943 and the election of Patriarch Aleksii, Bishop Afanasii distributed a letter to believers, in which he acknowledged the legality of the new first priest (the patriarch) and called for unity with the patriarchal Church. According to some undocumented rumors, in the 
deep provinces, separate individuals and even groups still remain who refuse to have any relations with the patriarchate, but, if this is true, their influence is insignificant.

Representatives of the Catacomb Church had as their goal to preserve the purity of the spirit of Orthodoxy, carrying it through the years of church struggle, repression, maneuvers, and compromises. They included prominent servants of Christ who had enormous influence on people searching for a genuine church life. Unfortunately, few memoirs, documents, and testimonies about them have been preserved. An exception is Bishop Afanasii, whose compiled materials and biographies have been partially collected and published..$^{76}$ Below, we will introduce memoirs about several priests of the Catacomb Church, among which one of the best is the memories of Archimandrite Serafim (the former confessor of Bishop Afanasii).

Fr. Serafim (in the world, Sergei Mikhailovich Batiukov) ${ }^{77}$ was born in 1880 in Moscow. In his early years, he felt called to service in the Church, although he became a priest only later in his life. Having received a technical education, Sergei Mikhailovich worked in one of the enterprises in the capital city. At the same time, he began to visit the Optina Pustyn' Monastery, attended lectures at the Moscow Theological Academy, and studied theology and sacred literature. He was a multifaceted, gifted person, with wide interests, and completely devoted to the Church.

Like two other leading activists in the Russian Church, Fr. Sergii Bulgakov and Archbishop Luk Voino-Iasenetskii, he was ordained during the most difficult time for the Church. ${ }^{78}$ In 1919 and for several months afterward, he served in the Church of the Resurrection in Sokol'niki, together with Fr. Ivan Kedrov, the Father Superior of the Church and the founder of the "Sokol'niki" community. ${ }^{79}$

Before that, church officials proposed that Fr. Sergii become head priest in the Church of the Resurrection of Christ, which existed by the conservatory. But Sergii took pity and gave his spot to the young priest Fr. Dmitrii Delektorskii, who would have been doomed to death if he had been sent to serve in the countryside. ${ }^{80}$

In 1920, Patriarch Tikhon summoned Fr. Sergii and appointed him to the Church of the Sacred Martyrs Cyril and John on Solianka Street. In 1922, he took monastic orders with the name of Serafim, and, at the end of 1926, the Church elevated him to the rank of archimandrite. According to rumors, his superiors prepared him for service in the church hierarchy.

Shortly thereafter, Fr. Serafim was arrested on the charge of concealing church valuables. This was a time when the majority of religious people and laypeople suffered while protecting their sacred objects. Subsequently, the 
case against Fr. Serafim was dismissed, since it turned out that some Serbians had removed the valuables (they were found in the courtyard of the Church of the Sacred Martyrs Cyril and John).

The archimandrite [Fr. Sergii] had a negative reaction to the declaration [1927] of Metropolitan Sergii. In July 1928, he left the church and went into illegal status. Fr. Ieraks (in the world Ivan Matveevich Bocharev), who served there from 1929 to 1932, also took the same pathway. From this time on, all religious people who refused to accept the declaration of Metropolitan Sergii were arrested (if they did not manage to hide themselves), and their churches were closed.

Only by a miracle did Fr. Serafim escape arrest. For some time, he lived secretly in various places, and in the end settled in Sergiev Posad (renamed Zagorsk) at the home of two sisters, nuns from Diveevo. ${ }^{81}$

There, in a small room, an altar was placed before the icon of the Iverskaia Mother of God, and there the liturgy was celebrated. ${ }^{82}$ Here many religious people conducted the worship service. In the interval between his arrests, Bishop Afanasii, in whose jurisdiction Fr. Serafim served, also frequented the house ${ }^{83}$ In this unremarkable house on the outskirts of town, the spiritual children of the archimandrite, seeking advice and comfort, gathered from everywhere. During the years of denunciations and incessant arrests (until 1943), it is remarkable that this church center remained intact for so long.

In his pastoral activity, Fr. Serafim, like the Fathers Mechev ${ }^{84}$ was guided by the advice of the Optina Elder Nektarius, ${ }^{85}$ who in that time had already left the destroyed Optina Pustyn' Monastery. In addition, Elder Zosima (in the Zakhariia skit), who came to Moscow from the closed Trinity-Sergiev Lavra, served as Fr. Serafim's mentor.

Fr. Serafim was a true adherent of traditional eldership. He always had a deeply individualized approach to people. As pastor, he conversed separately with each person, and his advice was conveyed only to the given person (he often even forbade transferring it to others). He saw his main calling as a shepherd, a nourisher of souls, and "a protector of the purity of Orthodoxy."

Among the like-minded thinkers gathered around Fr. Serafim was the outstanding above-mentioned Fr. Pyotr Shipkov (1881-1959). Consecrated in 1921, he went into the "catacombs" approximately at the same time as Fr. Serafim. Fr. Pyotr worked as a bookkeeper in Zagorsk and conducted his services in private homes. He was a person of inexhaustible life-giving joy and of some unusual spiritual light. Years of hard experience (cumulatively, he was imprisoned for nearly thirty years) did not place the stamp of bitterness and hardness on him. He was fated to live a long time after Fr. Serafim, 
who died in 1942, and, following his exile, to finish his days as the head priest in the cathedral in the city of Borovsk.

Fr. Ieraks lived in Bolshevo, outside Moscow, in the home of one of his spiritual daughters. ${ }^{86}$ The owner of the house had to hide from her relatives [the fact] that a church was located in her attic and a priest lived there. Fr. Ieraks was arrested in this home in 1943. Subsequently, like Fr. Pyotr, the authorities rehabilitated and freed him. The labor camp experience and exile severely damaged his health, so that he could no longer serve. Fr. Ieraks died in Vladimir, while a pensioner of the patriarchate.

Although the following memoirs were not intended for publication and are distinguished by their intimately personal character, they retain their significance as an historical document and spiritual witness. Because the images of "catacomb" priests are depicted through the prism of the internal biography of the author, we see in these images the elders' guidance in all its concreteness and depth. The memoirs show how intently Fr. Serafim and Fr. Pyotr devoted themselves to the smallest movements of the souls under their guidance, how they engaged with everyone who came to them, suffered with them, supported them, and helped them with advice and prayer. We learn about their relationship to very different circumstances and life's problems, and this, if you will, better than any chronicle, offers new generations a view of the spirit of the Catacomb Church and its pastors.

The author of the writings, Vera Iakovlevna Vasilevskaia, was a research scientist, a specialist in pedagogy and mental and physical disabilities. She graduated from the Philosophy Faculty of Moscow University and the Institute of Foreign Languages. To her belongs a series of works, some of which are published. The main one of them is Ponimanie uchebnogo materiala uchashchimisia vspomogatel'noi shkoly (Moscow: AN SSSR, 1960). To her also belongs translations of books: E. Kheisserman, Potentsial'nye vozhmozhnosti psikhicheskogo razvitiia normal'nogo i nenormal'nogo rebenka (Moscow: Nauka, 1964); K. De Griunval'd, "Kogda Rossiia imela svoikh sviatykh" (unpublished); and Frantsisk Sal'skii, Vvedenie v blagochestivuiu zhizn' (Brussels: Zhizn's Bogom, 1967). She began writing her memoirs nearly twenty years ago and completed them in $1959 .{ }^{87}$ 

WOMEN OF THE CATACOMBS 


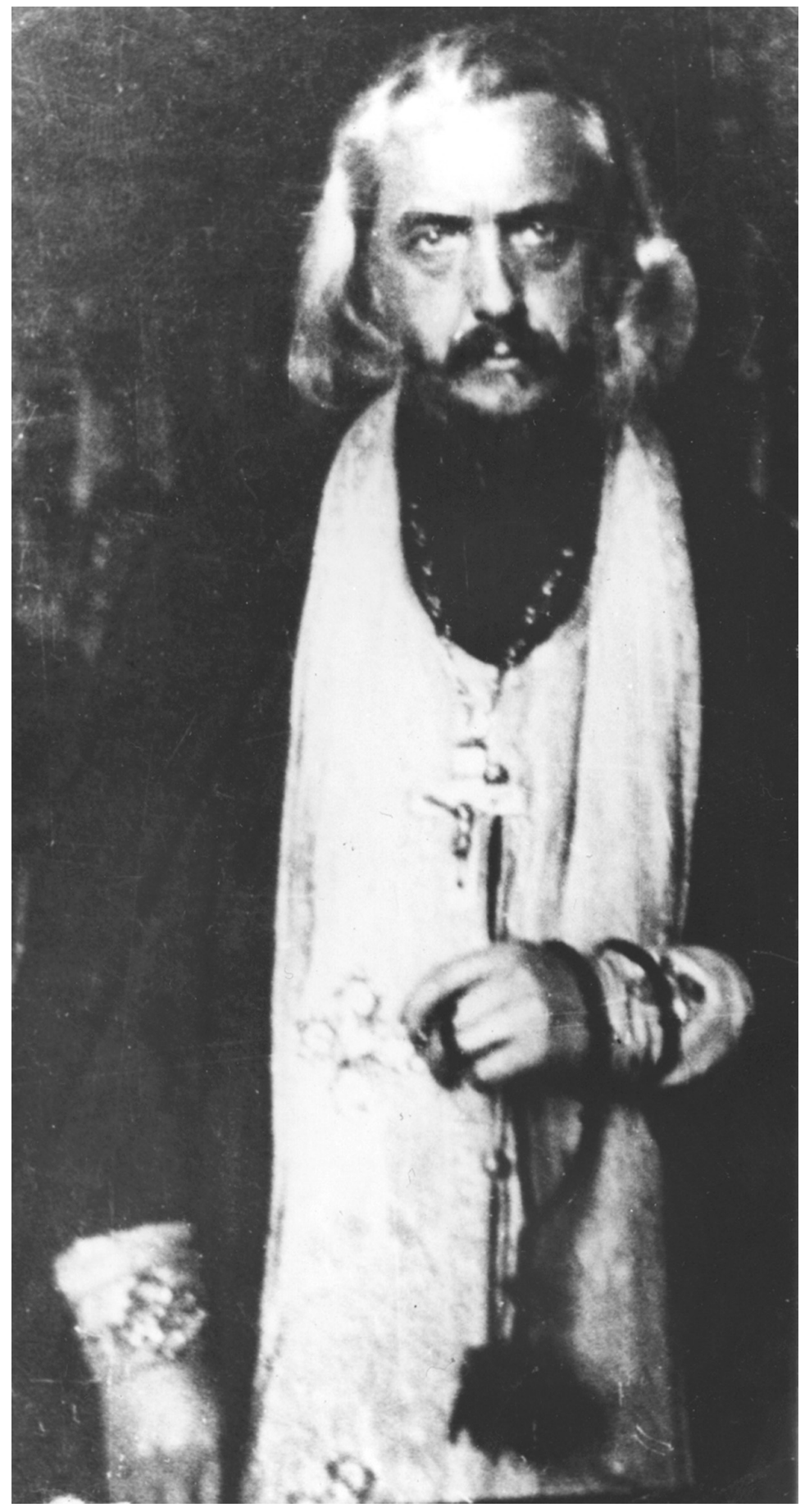

FIGURE 1. Archimandrite Serafim (Batiukov) 